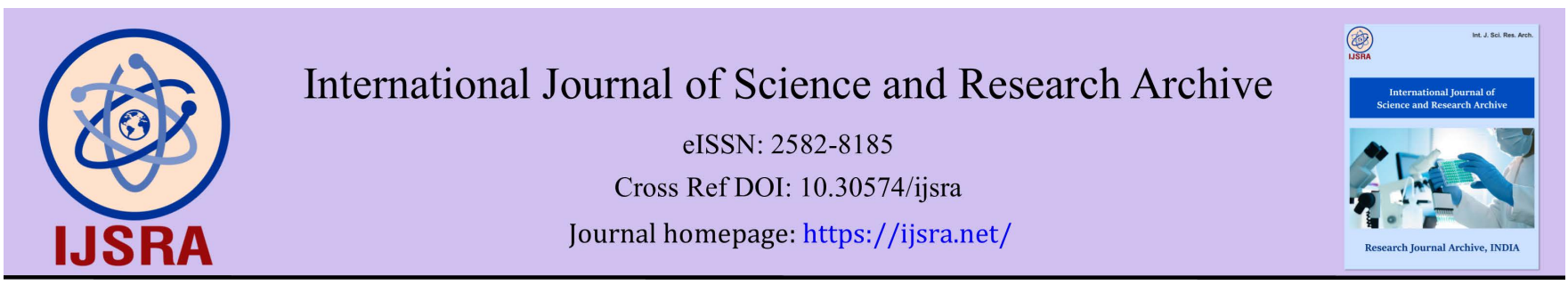

(RESEARCH ARTiClE)

\title{
Physiochemical analysis of oil extracted from Vitelleria paradoxa seed obtained from Wukari North Eastern Nigeria
}

\author{
Azuaga TI $1{ }^{*}$, Azuaga IC ${ }^{2}$, Okpaegbe UC ${ }^{1}$, Ibrahim AI ${ }^{1}$ and Manasseh CK ${ }^{1}$ \\ ${ }^{1}$ Department of Chemical Sciences, Federal University, Wukari-Nigeria. \\ 2 Department of Chemical Sciences, Taraba State University, Jalingo.
}

International Journal of Science and Research Archive, 2021, 04(01), 059-066

Publication history: Received on 10 October 2021; revised on 20 November 2021; accepted on 22 November 2021

Article DOI: https://doi.org/10.30574/ijsra.2021.4.1.0174

\begin{abstract}
Soxhlet extraction of oil from seeds of Vitelleria paradoxa was carried out using n-hexane as the solvent. Standards methods were adopted in the analysis of the physiochemical properties; moisture content, melting point, total ash content, $\mathrm{pH}$, specific gravity, iodine value, saponification value, acid value, free fatty acid value and ester value were all evaluated. The oil recovery rate was good with $32.6 \%$ yield, moisture content of $3.1 \%$, melting point of $52 \mathrm{oC}$ and $\mathrm{pH}$ 5.7. Total ash content was 50.3\%, specific gravity of $0.9 \mathrm{~g} / \mathrm{cm} 3$, iodine value $39 \mathrm{mg} / \mathrm{L}$, saponification value 224.6 $\mathrm{mgKOH} / \mathrm{g}$, acid value $59.9 \mathrm{mgKOH} / \mathrm{g}$ free fatty acid (FFA) $29.9 \mathrm{mgKOH} / \mathrm{L}$ and ester value $164.7 \mathrm{mg} / \mathrm{L}$. The results shows that oil from Vitelleria paradoxa seed holds the potentials for wider applications in foods, cosmetics, pharmaceuticals, lubricants and soap making.
\end{abstract}

Keywords: Physiochemical; Extraction; Analysis; Vitelleria paradoxa; Oil; Moisture content

\section{Introduction}

Globally, there has been an increase in the demand for vegetable oils, and oils from vegetable sources have continued to enjoy prominence over animal fats. This can be attributed to it perceived health benefits as compared with animal fat.

The low or complete absence of cholesterol, high content of unsaturated free fatty acids, low cost, purity, stability among many other food processing benefits are important nutritional considerations in food processing, [1]. Physiochemical parameters of oil greatly influence the general characteristics of the oil and ultimately its usefulness for various industrial applications.

Over the last 20 years, there has been considerable progress in utilization of vegetable oils and their derivatives in the formulation of bio-lubricants and the versatility of vegetable based fluids and downstream esters is now recognized in research projects in many areas where a number of applications may not have been previously possible, but where modification of the equipment or process designs themselves can enable potential advantages for users [2]. Vitellaria paradoxa (the Shea tree), is an indigenous wild tree of African savannah parkland [3]. Vitellaria paradoxa tree has been included in the priority list of African Genetic Resources by the FAO [4]. Shea butter is as good as table oil because of its high nutritive value and low cholesterol levels; widely used locally for curing leprosy and other ailments and has various industrial uses that include soap making, cosmetics, lubricants and paints [5]. The shea fruit is usually eaten, and the seed discarded as waste. However, upon processing, nuts/seeds of Vitelleria paradoxa gives an oil with so many desirable constituents. According to Maranz, et.al, [6] and Aulander [7], the shea butter fat can be used in the areas of

\footnotetext{
* Corresponding author: Azuaga TI

Department of Chemical Sciences, Federal University, Wukari-Nigeria.

Copyright (@ 2021 Author(s) retain the copyright of this article. This article is published under the terms of the Creative Commons Attribution Liscense 4.0.
} 
soap making, cosmetics and traditional medicine in many rural areas. Nigeria has the potential of leading the world, and sustains its leading role in Africa in the area of oleo chemical and biodiesel production from vegetable oil because of many plant species with seeds suitable for oil extraction.

In Wukari- north eastern Nigeria, shea tree nuts (Vitelleria paradoxa) Butyrospernum are usually discarded as waste product; in recent past, processing of shea nuts and production of shea butter are practiced by the collectors of the shea nuts who are in most cases rural women, each using their own local approach and methods. Local production of shea butter revealed problems which include inconsistent product and the difficulty to control or procure consistent product due to lack of quality control leading to degraded quality shea butter. Therefore, this study was designed to extract shea butter and determine the physicochemical properties with a view of addressing inconsistencies associated with local production of the oil, thereby increase its scope of usage.

\section{Material and methods}

\subsection{Sample Collection/preparation and Oil Extraction}

Shea (Vitelleria paradoxa) seeds were collected from their natural habitat in wukari local government area in Taraba State, north-eastern Nigeria. The seeds were dehulled, cleaned and dried under the sun for a day and later dry in the oven for three hours at $50{ }^{\circ} \mathrm{C}$ to ensure that moisture content is reduced to the bearest minimum.

The prepared seed were oven dried at70 ${ }^{\circ} \mathrm{C}$ until a constant weight was obtained, then grinded into sizes. $300 \mathrm{~g}$ of the grounded Vitelleria paradoxa seeds were weighed into a thimble (semipermeable membrane) and placed into the soxhlet extractor with $450 \mathrm{ml}$ of $\mathrm{n}$-hexane solvent. The solid particles were removed by filtration to get the extracted lipids. The extracted oil was then analysed for the physical and chemical properties. All reagents used were of analytical grade.

\section{Physicochemical Analysis}

\subsection{Moisture Content Determination}

$50 \mathrm{~g}$ of the clean sample was weighed and dry in an oven at $80^{\circ} \mathrm{C}$. After every 2 hours, the sample was removed from the oven and place in the desiccator for 30 minutes to cool. It was then removed and weighed [8]. The percentage moisture in the seed was then calculated from

$$
\text { Moisture }=\frac{100(w 2-w 1)}{w 1} \%
$$

Where; W1 =0riginal weight of sample before drying (g), W2 =Weight of sample after drying (g)

\subsection{Melting Point Determination}

Samples were loaded by jabbing the open end of a capillary tube into a pile of the sample. With closed end down, the tube was dropped down a long hollow tube so that it hits the bench top and packs the sample into the closed end of the tube. The sample was loaded to a height of $2-3 \mathrm{~mm}$ and placed into a slot in the MelTemp. The dial was then turned to begin heating. Heating was done at a medium rate of $2^{\circ} \mathrm{C}$ below the expected melting point and then heated very slowly $\left(1^{\circ} \mathrm{C}\right.$ every 30 seconds).

The temperature where the first droplet of liquid is seen (there is movement in the tube) was recorded.

The second temperature when the entire sample liquefies (the entire sample changes from opaque to transparent) was also recorded. The melting range was recorded (e.g. $120-122^{\circ} \mathrm{C}$ ).

\subsection{Determination of Total Ash Content}

About 5 grams of the sample was weighed (in duplicate) in a tarred crucible and placed in a cool muffle furnace. It was then burnt for $12-18$ hours (or overnight) at a temperature of about $550^{\circ} \mathrm{C}$. The muffle furnace was turned off and allowed to cool to at least $250^{\circ}$ C. The door to the muffle furnace was opened gently to avoid losing ash that may be fluffy. Safety tongs was used to transfer crucibles to a desiccator. The desiccator was closed after the crucibles are covered to 
cool to room temperature. It will be weighed thereafter. The values were recorded and the ash content was calculated using

$$
\% \text { ash (wet basis) }=\frac{w t \text { after ashing-tare wt of crucible }}{\text { original sample weight }} \times 100
$$

\section{4. pH Determination}

A total of $2 \mathrm{~g}$ of the sample was poured into a clean dry $25 \mathrm{ml}$ beaker and $13 \mathrm{ml}$ of hot distilled water was also added to the sample in the beaker and stirred slowly. It was then cooled in a cold water bath to $25{ }^{\circ} \mathrm{C}$. The pH electrode was standardized with buffer solution and the electrode was then immersed into the sample. The pH value was read and recorded [8].

\subsection{Specific Gravity Determination}

The specific gravity bottle was cleaned with acetone, ether and dried in an oven at $60^{\circ} \mathrm{C}$. The weight of the empty bottle was recorded, after which the bottle was filled with the oil sample and properly covered. The weight was recorded using a weighing balance, after which the sample was removed from the bottle. The bottle was properly washed and filled with distilled water, after which the weight was taken and finally, the specific gravity was computed using the relationship below

$$
\text { Specific gravity }=\frac{w 0-w}{w 1-w}
$$

where, $\mathrm{W}=$ Weight of empty bottle $(\mathrm{g})$, Wo = weight of the bottle and oil content $(\mathrm{g})$, W1 = Weight of bottle and water content (g).

\subsection{Iodine Value Determination}

Approximately $0.2 \mathrm{~g}$ of liquid fat or oil was weighed accurately into a titration vessel. In the case of fats which are solid at room temperature, they were warmed gently in a microwave oven beforehand. $10 \mathrm{~mL}$ cyclohexane was added to dissolve. $0.5 \mathrm{~mL}$ mercuric acetate solution and $20 \mathrm{~mL}$ glacial acetic acid was also added. In the case of high melting point fats, it is useful to add the cyclohexane to the titration vessel before weighing. The fat was dropped directly into the cyclohexane aids dissolution. However, it is important to rapidly tare the balance and add the sample, just allowing the balance to stabilize before recording the mass.

The titration procedure is designed to eliminate operator involvement in the determination. The Wijs' solution was added, with a 300 seconds (5 minutes) wait programmed before $10 \mathrm{~mL}$ of $15 \%$ KI solution is added. The titration commenced automatically. The reaction with the Wijs' solution was carried out in the dark, although low room lighting is probably satisfactory.

After titration, the titration assembly was rinsed first with DI water, then with alcohol (methylated spirits). It was then gently wiped dry prior to the next titration.

The iodine value was determined using the relationship below

$$
\begin{gathered}
\text { lodine Factor }(I F)=\frac{0.01269 \times \mathrm{M} \mathrm{Na}_{2} \mathrm{~S}_{2} \mathrm{O}_{3}}{0.1} \\
\text { lodine Value }(I V)=\frac{((\text { blank }- \text { titration }) \times I F \times 100)}{\text { sample mass, } g}
\end{gathered}
$$

\subsection{Saponification Value Determination}

About $0.5 \mathrm{M} \mathrm{KOH}$ was prepared in $95 \%$ ethanol, $2 \mathrm{~g}$ of oil sample was then weighed and $25 \mathrm{~cm}$ of KOH was added. 25 $\mathrm{cm}^{3}$ of the blank solution was also measured into a conical flask. The two samples was then connected to a reflux apparatus and allow to boil for an hour until the reflux is completed, $1 \mathrm{~cm}^{3}$ of phenolphthalein was added to the mixture and the resulting mixture was titrated while hot against $0.5 \mathrm{M} \mathrm{HCl}$ acid solution. The volume of the acid was used to attain the end point which was then recorded, the blank determination was carried out using the same procedure 
described above until the colour changes from blue to transparent white, and then the volume of acid used was noted. The Saponification value was determined using the relationship below

$$
\text { Saponification Value, }(\mathrm{S} . \mathrm{V})=\frac{56.1 * T(V o-V 1)}{M}
$$

Where, $\mathrm{T}=$ Molarity of the standard $\mathrm{KOH}$ solution used (M), Vo = Volume of acid used for the first titration with oil sample $\left(\mathrm{cm}^{3}\right), \mathrm{V} 1=$ Volume of acid used for the second titration of the blank solution $\left(\mathrm{cm}^{3}\right), \mathrm{M}=\mathrm{Mass}$ of the oil sample used (g).

\subsection{Acid Value Determination}

About $2 \mathrm{~g}$ of the sample was dissolved in $50 \mathrm{~cm}^{3}$ of mix neutral solvent $\left(25 \mathrm{~cm}^{3}\right.$ diethyl ether with $25 \mathrm{~cm}^{3}$ ethanol carefully neutralized with $0.1 \mathrm{M} \mathrm{NaOH}$ using $1 \%$ phenolphthalein solution). The mixture was titrated with $0.1 \mathrm{M} \mathrm{NaOH}$ aqueous solution with constant shaking to faint pink colour

$$
\text { Acid value }=\frac{\text { titre value } * 5 * 61 * 0.00282}{\text { weight of sample }(\mathrm{g})}=\mathrm{mgKOH} / \mathrm{g}
$$

\subsection{Free Fatty Acid Determination}

The amount of free fatty acid (FFA) was calculated as being equivalent to half the value of acid value [8], that is,

$$
\text { Acid value }=\frac{\text { Acid value }}{2}=m g \mathrm{KOH} / \mathrm{g}
$$

\subsection{Ester Value Determination}

About $2 \mathrm{~g}$ of the sample was placed in a tarred, 250-mL flask and accurately weighed. 20-30 mL of neutralized alcohol was added and shaken. $1 \mathrm{~mL}$ of phenolphthalein TS was added, and titrated with $0.5 \mathrm{~N}$ alcoholic potassium hydroxide VS until the free acid is neutralized. $25.0 \mathrm{~mL}$ of $0.5 \mathrm{~N}$ alcoholic potassium hydroxide VS was added, and proceed as directed under Saponification Value, beginning with "Heat the flask" and omitting the further addition of phenolphthalein TS. The Ester Value was then calculated by using the formula:

$$
[56.11(\mathrm{VB}-\mathrm{VT}) \mathrm{N}] / \mathrm{W} \text { USP35 }
$$

Where, 56.11 is the molecular weight of potassium hydroxide; VB and VT are the volumes, in mL, of $0.5 \mathrm{~N}$ hydrochloric acid consumed in the blank test and in the actual test, respectively; $\mathrm{N}$ is the exact normality of the hydrochloric acid; and $\mathrm{W}$ is the weight, in $\mathrm{g}$, of the substance taken for the test.

\section{Results and discussion}

\subsection{Percentage Yield}

The percentage yield of oil was calculated using the expression below

$$
\text { Percentage yield }=\frac{\text { Weight of oil }}{\text { Weight(g)of sample (Shea nut) }} \mathrm{X} 100
$$

Where:

Weight of the shea nut $=300 \mathrm{~g}$, weight of the oil obtained $=98 \mathrm{~g}$

$$
\begin{aligned}
& \text { Percentage yield }=\frac{98}{300} \times 100 \\
& \text { Percentage yield }=32.67 \%
\end{aligned}
$$

Shea nut oil yielded significantly lower oil (32.67\%) compared to the oil yield of $44.65 \%$ reported by Misbaudeen et al., [9]. It is also lower compared to the yields of $40.1 \%$ reported by Applequist et al. [10] in C. argyrosperma var. cushaw green striped. The obtained oil yield values indicate that shea butter nut is a good oil source particularly when compared 
to soybeans (20\%) and sunflower (32.0\%) seeds. According to Akinoso and Raji [23], any seed containing greater than $17 \%$ of oil is considered an oil seed. Therefore, shea nut oil can be utilized for industrial vegetable oil purposes.

\subsection{Physicochemical Composition}

The physicochemical properties of oil obtained from Vitellaria paradoxa is shown in Table 1

Table 1 Physicochemical properties of oil from Vitellaria paradoxa

\begin{tabular}{|l|c|}
\hline Parameters & Quantities \\
\hline Moisture content & $3.051 \%$ \\
\hline Melting point & $52^{\circ} \mathrm{C}$ \\
\hline Total ash content & $50.32 \%$ \\
\hline $\mathrm{pH}$ & 5.65 \\
\hline Specific gravity & $0.87992 \mathrm{~g} / \mathrm{cm}^{3}$ \\
\hline Iodine value & $38.9712 \mathrm{mg} / \mathrm{L}$ \\
\hline Saponification value & $224.642 \mathrm{mg} / \mathrm{L}$ \\
\hline Acid value & $59.95 \mathrm{mg} / \mathrm{L}$ \\
\hline Free fatty acid value & $29.975 \mathrm{mg} / \mathrm{L}$ \\
\hline Ester value & $164.692 \mathrm{mg} / \mathrm{L}$ \\
\hline
\end{tabular}

\subsection{Moisture Content}

Moisture is a chemical contaminant which is usually well mixed with oil. Presence of moisture in oil affects the quality of the oil, it has been reported that significant amount of moisture in oil support microbial growth [11] The moisture content of Shea oil was obtained to be $3.051 \%$ which signifies that it has low potential for rancidity to occur. Low moisture content is desirable in oil to preserve the shelf-life because oxidative rancidity, microbial growth and infestation are prevented or reduced by moisture removal. The value of the moisture is higher compared to that reported by Asuquo et al. [12] which was $0.1 \%$. The difference observed could be due to the level of maturity of the shea seeds or the method of extraction employed.

\subsection{Melting Point}

Melting point is the temperature at which transition from solid to liquid state is observed. Thus, at this temperature a fat melts on the application of heat. The melting point of Shea butter in this study was found to be $52^{\circ} \mathrm{C}$. It is higher than the melting point of groundnut $\left(35^{\circ} \mathrm{C}\right)$ obtained by Amita and Khatkar. The [13] of Shea-butter makes it ideal for the preparation of creams which go into chocolates. Lipids that contain large amounts of saturated fatty acid (e.g. vegetable oil) have low melting point which is related to differences in the 3D shapes between the hydrocarbon chains [14].

\subsection{Total Ash Content}

The ash content of oil is the residue of its organic component when the oil is burnt off in air. The ash consists of the inorganic components in the form of their oxides. The ash content obtained for Shea-butter is $50.3 \%$. This value is higher than $4.51 \%$ ash content of Shea nuts obtained by Misbaudeen et al. [9]. It is an indication that there a lot of minerals or organic materials present in the Shea-butter obtained in this study.

\section{6. $\mathrm{pH}$}

$\mathrm{pH}$ is the measure of the reactive amount of free hydrogen ions in a liquid. In this study, Shea oil had a pH of 5.7. This value is fairly higher than the $\mathrm{pH}$ value of sesame oil 4.33 [15]. The low $\mathrm{pH}$ value of Shea oil signifies that it is acidic and may not be good for human consumption.

\subsection{Specific Gravity}

Specific gravity is an important physical property that can give information on the identity of the sample as well as aid in detection of adulteration of shea butter oil [16]. It can also provide information for the shippers on the weight of the 
shea butter from the given volume while exporting it in large volumes [17]. The specific gravity for this oil was determined to be $0.8799 \mathrm{~g} / \mathrm{cm}^{3}$. This value is lower than $0.927 \mathrm{~g} / \mathrm{cm}^{3}$ of Shea butter obtained by Chibor et al. [18]. The value obtained from this research shows close proximity to $0.8-1.0$ as the required standard.

\subsection{Iodine Value}

Iodine value is a measure of the degree of saturation of oil. In addition, it is an indicator of the storability of the oil. The iodine value of Shea-butter was determined to be $38.9712 \mathrm{mg} / \mathrm{L}$. The iodine value obtained from this study is lower than the values for SBSE (53.31) and SBCP (54.95), [9]. The extracted Shea butter could be useful for soap production because of its low degree of unsaturation and non-drying oil properties, but are not applicable for the production of paint where drying oils, such as linseed oil, of higher iodine values are desired. The lower the iodine numbers the lower the degree of unsaponification and the longer the shelf-life of the oil.

\subsection{Saponification Value}

Saponification value is the number of milligram of potassium hydroxide required to neutralize the free fatty acid resulting from complete hydrolysis of $1 \mathrm{~g}$ of the oil sample and saponify the esters in $1 \mathrm{~g}$ of fat [19]. The saponification value of Shea butter oil obtained was $224.642 \mathrm{mg} \mathrm{KOH} / \mathrm{L}$. The high saponification value is an indication that the Shea butter oil is a normal triglyceride molecule. This value is higher than those obtained by Misbaudeen et al. [9] which were 172.2 and $185.7 \mathrm{mg} \mathrm{KOH} / \mathrm{L}$ for samples of SBSE and SBCP, respectively. The higher the saponification value of the oil, the higher is the lauric acid content of that oil. The lauric acid content and the saponification value of the oil serve as important parameters in determining the suitability of the oil in soap making [12].

\subsection{Acid Value}

The acid value of oil is the number of milligrams of Potassium Hydroxide (KOH) needed to neutralize $1 \mathrm{~g}$ of the oil sample. Acid value is a measure of the extent to which glyceride in the oil has been decomposed by lipase or other actions such as heat and light. The acid value of the shea butter oil was found to be $59.95 \mathrm{mg} \mathrm{KOH} / \mathrm{L}$. The acid value obtained in this study is higher than that obtained from the work of Enweremadu and Alamu, [20] who obtained $3.62 \mathrm{mg} \mathrm{KOH} / \mathrm{L}$ for acid value of Shea nut oil. Oil is considered acidic if its acid value is greater than $2 \mathrm{mg} / \mathrm{L} \mathrm{KOH} \mathrm{g}^{-1}$ oil [21]. However, the acid value of shea-butter may not be harmful to the body, since it is not consumed extensively like groundnut oil within the country.

\subsection{Free Fatty Acid}

Acid value is expressed as the percentage of Free Fatty Acids (FFA). The corresponding free fatty acid value of Shea oil obtained was $29.975 \mathrm{mg} / \mathrm{L}$. The free fatty acid value in this study is higher than the free acid value of $1.62 \mathrm{mg} / \mathrm{L}$ which was obtained by Enweremadu and Alamu, [20].

\subsection{Ester Value}

The ester value of a fat is a function of the saponification value and the acid value. It is an indication of the saponifiable fatty acids excluding the free acids of the fat [22]. The ester value of Shea nut oil was found to be $164.692 \mathrm{mg} / \mathrm{L}$. This value is lower than the ester value of Shea nut oil $(226.17 \mathrm{mgKOH} / \mathrm{L})$ and higher than that of fluted pumpkin seed oil (177.63 mgKOH/L) obtained by Chibor et al., [18]. The high ester value of Shea butter oil is an indication that the fats are suitable for culinary purposes

\section{Conclusion}

Shea nut oil in this study gave high yield of $32.67 \%$ and so can be considered an oil seed; it is chemically safe for culinary purposes. The physicochemical properties of the extracted oil offer it the potentials for industrial applications. The availability of numerous minerals in the nut resulted in the high ash content obtained. The acid value, saponification value and iodine values in this study indicates that the oil is suitable for food, cosmetic, drugs, soap making and lubricants. The changes in acid and iodine values can, therefore, be used in monitoring deterioration of shea butter with a view of prolonging the shelf life of the oil. 


\section{Compliance with ethical standards}

\section{Acknowledgments}

This research was not funded by any external funding agency; however the authors are very thankful for the support of all the members of the Organic and Analytical research groups, Federal University Wukari \& Taraba State University Jalingo, for their contributions in making this paper a success.

\section{Disclosure of conflict of interest}

The authors declare no conflict of interest

\section{References}

[1] Okpaegbe UC, Magomya AM., Azuaga TI, Egah GO, and Kaaer SN. Proximate Analysis and Phytochemical Screening of Breadfruit (TreculiaAfricana) Seed Oil. The International Journal of Engineering and Science. 2021; 10(2): 71-76.

[2] Lea C. The versatility of biolubricants. Oils and Fats International Journal. 2003; 29(1): 26-28.

[3] Hall JB, Aebischer DP, Tomlinson HF, Osei-Amaing E, Hindle JR. Vitelleria paradoxa. A monograph. Bangor: School of Agricultural and Forest Sciences, University of Wales. 1996.

[4] Food and Agriculture Organization, FAO. 'The State of Food Insecurity in the World'. The United Nations Viale delle Terme di Caracalla, 00100 Rome, Italy. 2002.

[5] Olaniyan AM, Oje K. Quality characteristics of Shea butter recovered from Shea kernel through dry extraction process. Journal of Food Science Technology. 2007; 44: 404 - 407.

[6] Maranz SZ, Wiesman J, Bisgaard J, Bianchi G. Germplasm resources of vitellaria paradoxa based on variations in fat composition across the species distribution range. Agroforestry System. 2004; 60: 71 - 76.

[7] Alander J. Shea butter - a multi-functional ingredient for food and cosmetics. Lipid Technology. 2004; 16 : 202 205.

[8] [8]. Akpan UG, Jimoh A, Mohammed AD. Extraction, characterization and modification of castor seed oil. Leonardo Journal of Sciences. 200; 6(8): 43-52.

[9] [9]. Misbaudeen A, Abdulrafiu OJ, Samuel AA. Comparative studies of thermo physical and physicochemical properties of Shea butter prepared from cold press and solvent extraction methods. Journal of King Saud University Science. 2020; 32: 2343-2348.

[10] Applequist WL, Avula B, Schaneberg BT, Wang YH, Khan IA. Comparative fatty acid content of seeds of four Cucurbita species grown in a common (shared) garden. Journal of Food Composition Analysis. 2006; 19(6-7): 606-611.

[11] Alirezalu A, Farhadi N, Shirzad H, Hazarti S. The effect of climatic factors on the production and quality of castor oil. Nature and Science. 2011; 9(4): 15-19.

[12] Asuquo JE, Anusiem ACI, Etim EE. Extraction and characterization of Shea butter oil. WOJAST. 2010; 2(2): 282 288.

[13] Amita D, Khatkar BS. Thermo-Physical Properties of Fats and Oils. International Journal of Engineering and Technical Research. 2017; 7(2): 2454-4698.

[14] Brown WH. Introduction to Organic and Biochemistry Book (pp.322-342). California, USA: Cole Publishing Company. 1987.

[15] Paul ED. Extraction and Characterization of Oil from Sesame Seed. Research Journal of Pharmaceutical, Biological and Chemical Sciences. 2013; 2(4): 752.

[16] Hee SN. Quality characteristics of West African Shea butter (vitellaria paradoxa) and approaches to extend shelf -life. Journal of Science, Technology, Mathematics and Education. 2011; 8(2): 73.

[17] Hamilton RJ, Rossell JB. Analysis of oils and fats. Elsevier Applied Science. New York. 1986. 
[18] Chibor BS, Kiin-Kabari DB, Eke-Ejiofor J. Physicochemical Properties and Fatty Acid Profile of Shea Butter and Fluted Pumpkin Seed Oil, a Suitable Blend in Bakery Fat Production. International Journal of Nutrition and Food Sciences. 2017; 6(3): 122-128.

[19] Hui L. Edible Oil and Fat Products: Oils and Oil seeds, Bailey's Industrial Oil and Fat Products (5th edition), New York, NY: John Wiley and Sons, Inc. 1996; 2: 109-110.

[20] Enweremadu CC, Alamu OJ. Development and characterization of biodiesel from Shea nut butter. International Agrophysics. 2009; 24: 29 - 34.

[21] Food and Agriculture Organization, FAO. 'Manuals of food quality control and food analysis, quantity adulteration and test of identity', FAO Food and Nutrition paper 14/8, United Nations, Rome. 1979; 255-290.

[22] Aremu MO, Ibrahim H, Bamidele TO. Physicochemical characteristics of the oils extracted from some Nigeria Plant Food A. Review. Chemical and Process Engineering Research. 2015; 23: 2224-77467.

[23] Akinoso R, Raji AO. Optimization of oil extraction from locust beans using response surface methodology. European Journal of Lipid Science and Technology. 2010; 113(2): 245-252. 